\title{
HUSSERL, THE DIFFEREND AND \\ KAFKA'S THE TRIAL
}

Kafka's The Trial is remarkable, amongst other reasons, for the description of the dissolution of K's confused and painful life-world.' Not unlike Elaine Scarry's account of the phenomenon of torture in The Body in Pain, $^{2} \mathrm{~K}$ slowly loses his familiar language through which he speaks and writes in his daily social relations with others. $K$ still speaks the words which represent the concepts with which he is familiar. And yet, his relationships with others become monologic. There seems to be no other who, unlike in his past private and professional life, can respond to his words in a manner with which $\mathrm{K}$ can understand. The others do respond. But they respond by emplanting meanings into K's words, meanings which only possess value within the discourses of self-styled legal experts and officials who act in K's name. The experts and officials take their own meanings as authoritative. $\mathrm{K}$ fails to gain access to their meanings. The question, posed by Husserl's phenomenology of language, is "why?".

Critics have taken different approaches to K's gradual isolation from the social - or, at least, what is taken as the social. ${ }^{3}$ Some have offered that The Trial exemplifies how a bureaucracy of a modem state works. More often, critics have suggested that The Trial exemplifies the consequences for social life when an existential philosophy is carried to the extreme. More recently, Jacques Derrida in his "Before the Law", interprets the story of the old man at the end of The Trial as erroneously searching for a center of the Law. ${ }^{4}$ Derrida suggests that the Old Man is not unlike all of us in that we invariably construct a center of a discourse in order for it to be a discourse. This, he calls the language of metaphysics. Drawing from Jean-Francois Lyotard's notion of a "differend", I wish to claim that The Trial represents a differend between two very different genres. Lyotard distinguishes a differend from a litigious dispute. ${ }^{5}$ Whereas the latter offers a shared language or, at least, shared meanings and signifiers through which a plaintiff may claim damages, there is no shared language to which a victim may represent her/his pain and suffering in a context where a differend exists. During the Holocaust, he suggests, there were no words to represent the pain

\section{5}

M. Kronegger and A-T. Tymieniecka (eds.), Analecta Husserliana, Vol. XLIX, I15-125. (c) 1996 Kluwer Academic Publishers. Printed in the Netherlands. 
incurred by survivors. Indeed, if a survivor attempted to represent her/his experience through legal language, s/he already participated in undermining the pain of the suffering. The suffering existed before speech.

$\mathrm{K}$ 's experiences seem to be not unlike Lyotard's account of the differend. $\mathrm{K}$ remains on the fringe of discourses which experts take as authoritative - that is, as having authority. Indeed, $\mathrm{K}$ remains on the fringe even of discourses shared amongst self-styled experts of authority. $K$ does not even know what forms or doctrines to associate with the utterances of the Chief Magistrate, his Lawyer, the Painter or even Block. Their utterances take on a meaninglessness for $\mathrm{K} . \mathrm{K}$ fails to receive meaningful responses to his enquiries. More correctly, although the experts, responses may be meaningful for their fellow experts, they remain meaningless for $K$. The doors of the Law always seem to remain open. And yet, $K$ never gains entry into the rooms of legal knowledge which he, not unlike the Old Man in the final story, believes to lie behind the doors. As K himself notes as he is refused permission to glance at the books of the Examining Magistrate in the empty courtroom, "these books are probably law books, and it is an essential part of justice dispensed here that you should be condemned not only in innocence but also in ignorance." The pain of K's experiences cannot be translated into the harm as authoritatively defined by the experts. A differend separates the discourse of the claimants to expert legal knowledge on the one hand and the discourses through which $\mathrm{K}$ lives his experiences from day to day. Just as he fails to respond to women, so too $\mathrm{K}$ fails to respond to the expert knowers in a manner which the expert knowers find meaningful. K's meanings remain unfulfilled. So too, the meanings of the expert knowers and women remain unfulfilled vis-à-vis $\mathrm{K}$. As a consequence, their meanings remain indeterminate with respect to each other.

K's experiential body slowly dies. This slow death occurs paradoxically at the very experiential moments when each knower believes her/him-self to be concerned with "K's case". The arresting officers, the tribunal, the lawyer, K's uncle, Fraulein Burstner's friend, Block, Leni, the manufacturer, the painter, the whipper, the gatekeeper and the executioners: each claims to possess inside knowledge about how the legal system works. Their concems originate with a concern about K's experiences. But drawing from their own experiences, not K's felt experiences, the expert knowers implant into K's actions and utterances special concepts associated with their own chains of signifiers. $\mathrm{K}$ is astonished to learn, for example, that the Lawyer knew about his case even before $\mathrm{K}$ had gone to talk with the Lawyer. When he presses the lawyer as to how he knew about his case, the Lawyer replies, "I'm a lawyer, you see, 1 move in legal circles where the various cases are discussed. ..." K's uncle notices that $\mathrm{K}$ is very nervous. The lawyer agrees. "Yes, added his uncle, 'You ask questions like a child."' The Lawyer continues rhetorically, "whom shall I associate with if not with men of my own profession?"

In his chapter entitled "The Lawyer", Kafka describes the very frustrating and estranged actions of his lawyer over his repeated meetings:

In such and similar harangues $\mathrm{K}$ 's lawyer was inexhastible. He reilerated them every time $\mathrm{K}$. called on him. Progress had always been made, but the nature of the progress could never be divulged. The lawyer was always working away at the first plea, but it had never reached a conclusion, which at the next visit tumed out to be an advantage, since the last days would have been very inauspicious for handing it in, a facl which no one could have foreseen.

The legal procedures never seemed to end although, for the lawyer, they were in fact exciting and challenging. Again and again, $\mathrm{K}$ is reminded that he possesses little knowledge of how the Courts actually work. As the Painter stated,

You don't seem to have any general idea of the Court yet. . . But since you're innocent you won't need it anyhow. I shall get you off all by myself?

When $\mathrm{K}$ asked "How can you do that? For you told me yourself a few minutes ago that the Court was quite impervious to proof", the Painter responded "Impervious only to proof which one brings before the Court. ... But it is quite a different matter with one's efforts behind the scenes: that is, in the consulting rooms, in the lobbies or, for example, in this very studio." The knowledge of the Law involves a secret knowledge which is circulated amongst experts who, because of their knowledge, are empowered to decide the fate of a non-expert such as $\mathbf{K}$.

The expert knowers believe that the legal procedures constitute the true/real. With a ravaging appetite, they circulate the "facts" of "K's case" through the intricate procedures with which only they are familiar. The experts interpret the actions of officials of the modern state. These officials are situated on a hierarchy whose ranks "mount endlessly" in the image of a pyramid. ${ }^{5}$ Each official plays a role in this hierarchy. Each communicates to her/his superior through a discourse which may well be meaningful only for those who command and receive in the hierarchy. A great deal is taken for granted amongst the expert knowers. Kafka gives 
the appearance that the experts share a common knowledge which they do not have to articulate. Indeed, the lower officials may not understand the signifiers of those higher on the hierarchy. Kafka describes the hierarchy in these terms:

The ranks of officials in this judiciary system mounted endilessly, so that not even the initialed could survey the hierarchy as a whole. And the proceedings of the Courts were generally kept secret from subordinate officials, consequently they could hardly ever quite follow in their further progress the cases on which they had wotked; any particular case thus appeared in their circle of jurisdiction often without their knowing whence it came. and passed from it they knew not whither. Thus the knowledge derived from a study of the various single stages of the case, the final verdict and the reasons for that verdict lay beyond the reach of these officials."

The arresting officers admitted as much.

Given the inaccessibility of the lower officials to the meanings of the higher officials, it is not surprising that K's meanings would slowly rupture vis-à-vis the discourses of the self-proclaimed experts. The more that the "clutches of the Court" envelop K's life, the more his links with what the experts take as the social, evaporate. Kafka describes K's felt experiences at one moment of rupture at the end of K's journey through the empty juridical offices:

he felt as if he were seasick. He felt he was on a ship rolling in heavy seas. It was as if the waters were dashing against the wooden walls, as if the roaring of breaking waves came from the end of the passage, as if the passage itself pitched and rolled and the waiting clients on either side rose and fell with it. All the more incomprehensible. ... At last be noticed that they were talking to him, but he could not make out what they were saying, he heard nothing but the din that filled the whole place, through which a shrill unchanging note like that of a siren seemed to ring.9

At another moment, when $\mathrm{K}$ had ventured to dismiss his lawyer, Kafka describes the gap between the lawyer's methods and the slow debasement of K's dignity:

It was humiliating even 10 the onlooker. So the lawyer's methods, to which K fortunately had not been long enough exposed, amounted to this: that the client finally forgot the whole world and lived only in the hope of roiling along this false path until the end of his case should come in sight. The client ceased to be a client and became the lawyer's dog. If the lawyer were to order this man to crawl under the bed as if into a kennel and bark there. he would gladly obey the order. ${ }^{10}$

The experts act as if their own little discourses constitute the social. But the social includes particular others only as understood and defined through the language of the experts.
$\mathrm{K}$ loses all linkage with what the experts take as the social. As Vygotsky and von Uexkull explain more generally," $\mathrm{K}$ could connect with the social only if he meant the experts' signifiers through his own environing world or Umwelt. At such a moment, if it were possible, his meanings and his relations with the others would become embodied. $\mathrm{K}$ experiences much more than the enclosure of his experiences by the typifications of the expert knowers, something which Alfred Schutz and his followers might suggest. $\mathrm{K}$ experiences an extraordinary gap between his utterances and the experts' lack of a response which is meaningful to $\mathrm{K}$.

\section{K'S MEANING CONFERRING ACTS}

It is at this point that Edmund Husserl's investigations of language can help one in a re-reading of The Trial. In volume two of the Logical Investigations, Husserl differentiates several elements in a language: a physical mark on a page or a physical sound in the air, a sign (or what de Saussure would call a signifier), an object of thought or signified, and a phoneme. Joseph $\mathrm{K}$ heard sounds when he awoke from his sleep. But the sounds awakened a meaning within him which the officials at his doorway did not accept. His meaning of the sounds, y-o-u-a-r-ea-r-r-e-s-t-e-d, involved the legal procedures of due process which one would expect in a liberal state. As K said to the officers' view of their role, "I don't know this Law." 2 And the warder replied, "All the worse for you." $\mathrm{K}$ insightfully noted "And it (the Law) probably exists nowhere but in your own head." $\mathrm{K}$ brings phonemes which he lives, phonemes connected with due process, into the physical sounds. K's phonemes are directed to the meaning of the sounds.

The sounds are gathered together into a sound pattern. Phonemes recognize the sound patterns. A mark or sound is "intrinsically indifferent," as Husserl would say. Once we only possess sound patterns, though, the formerly indifferent sounds become meaningful. A sound pattern awakens a meaning conferring act in ourselves in the direction of a referent. The sounds become intelligible to the receiver upon the recognition of them as a sound pattern. The meaning conferring possesses the character of an act. The conferring of meaning is an act because the speaker, drawing from the phonemes, intentionally points to an object through the sound pattern. ${ }^{13}$ The sound pattern can be described as what Husserl calls a sign or what de Saussure calls a signifier when 
one understands the marks or sounds. Because one's phonemes recognize sounds as patterned and because this pattern awakens the conferring of meaning in the direction of a referent beyond the sound pattern, the meaning conferring act lives. When one thereby brings meaning into a sound, the act undergoes "an essential phenomenal modification when its object begins to count as expression." ${ }^{14}$ As Husserl explains in the Fifih Investigation, "we live in the acts which give it (the object) sense: we are exclusively turned to the object that appears in such acts, we aim at it, we mean it in the special, pregnant sense."15 Through the act of conferring meaning, our understanding of the mark or sound thereby lives. Our understanding is embodied. Life replaces dead matter.

Now, Husserl suggests that there is a second moment in the experience of meaning: the meaning fulfillment act. The utterances of the experts to legal knowledge in The Trial "stir up" or "awaken" meanings for $\mathrm{K} . \mathrm{K}$ intends these meanings. They point in a certain direction. By themselves, the signifiers of the arresting officers, for example, arouse an intention in the officers which $\mathrm{K}$ takes as indeterminate. As indeterminate, their signs arouse a range of possible fulfillment. The intuitions of the experts fulfill the meaning conferring acts of their peers. At the moment of fulfillment amongst their peers, the utterance of an expert becomes determinate.

This determinacy remains absent in K's response to the utterances of the expert knowers. For, when $\mathrm{K}$ experiences events such as his arrest, his appearance before the Chief Magistrate, or his visit to the Painter, his phonemes either do not recognize sound patterns from the others or, if they do, his meanings conferred into the sound patterns point in a direction which the experts do not recognize. The utterances of experts remain indeterminate; that is, without a meaning which $\mathrm{K}$ can consider concrete. Thus, the interpretations of the expert knowers do not attach to the social circumstances surrounding K's pain. At most, the meanings conferred on events point in a direction of the event. More likely, their meaning conferring acts point towards signifiers with which other experts may mean. After all, without shared meanings, communication from one expert to another expert remains unfulfilled and, therefore, indeterminate. The communication loses its rhetorical value. The experts play toward each other's phonemes, at the very moment that they may claim to be unravelling the "facts" of K's case. The expert knowers for their part undergo a series of experiences which infiltrate into the signifiers representing the "facts of the case".

\section{THE FAILURE OF THE FULFILLMENT OF K'S MEANING CONSTITUTING ACTS}

The failure of $\mathrm{K}$ and the expert knowers of legal language to fulfill each other's meanings marks how $K$ and the experts speak through radically different languages. $K$ cannot respond to the experts and the experts cannot respond to $\mathrm{K}$ because the actors intend different meanings to the same event or statement. The same words signify or re-present different significations. K's pain cannot be translated into the representations with which the experts are familiar. And as the experts proceed to act in the name of K's case, K's pain becomes more and more unfulfilled and, therefore, magnified. A differend dwells between the two sets of meanings even when the actors utter the same words.

The differend between $\mathrm{K}$ 's meaning conferring acts and the meanings of the expert knowers in The Trial is manifested, first, from the failure of K's meaning conferting acts to be fulfilled from the experts' responses; and secondly, from the failure of the experts' meaning constituting acts to be fulfilled in K's responses. Husserl suggests that meaning may point either to an intuitive object or to a represented object. A represented object is a "mental image". If the meaning conferring act intends a representational object, the meaning is fulfilled or realized as meaning. ${ }^{16}$ If the relation to the object remains unrealized (that is, if the object is not intuitively before one as a named or meant object), it remains a mere meaning intention. The meaning remains empty or indeterminate. On the other hand, if $\mathrm{K}$ 's meaning conferring acts intend an object which experts also mean, $\mathrm{K}$ 's acts are fulfilled in the meaning constituting acts of experts. The thoughts as much as the actions of the expert knowers could serve as fulfilled objects. In Husserl's terms, "categorical" or "non-independent forms" may inform the object."

According to Husserl's analysis, then, K's interpretative acts involve two acts. First, K's meanings bring an intentional direction to bear upon the others' stories, gestures and commands as intentional objects. Secondly, though, Husserl's analysis offers that the experts must recognize or fulfill K's utterances as sound patterns. At that moment, the experts" meanings enclothe K's utterances "like a garment". K's expressive experiences fuse with the stories of the experts. The latter stories serve as referents for K's meanings. ${ }^{18}$ Without $\mathrm{K}$ 's intentional acts, hyletic data are unintelligible, according to Husserl. But without the second act - the meaning fulfilling act $-\mathrm{K}$ remains a linguistic monad. Until $\mathrm{K}$ 's 
meanings are determinatively fulfilled in relation to his intended objects, they remain indeterminate in their abstraction, though meaningful to $\mathrm{K}$ himself. ${ }^{19}$

Conversely, as $K$ hears the utterances of the experts, the meanings of the latter remain indeterminate in the sense that their universals demand an incompletely determined completion, as Husserl would put it. ${ }^{20}$ A universal circumscribes a "sphere" or boundary of meaning which remains open or unspecified until it grasps a particular referent. When an indeterminate thought points to an actual referent, the thought is made determinate. K's meaning acts are unfolded and unrealized in the "this" of the percept. His actual perceptions fail to fulfill his pre-existing meanings. K's intentions bring sensory experiences into signifiers. K's meanings live.

Now, at least since the Roman Republic (according to Hannah Arendt) or even before (perhaps at the time when King Archon is said to have "founded" the culture which eventually overthrew Mycenae and even Crete), the expert knowers of legal signifiers attempt to trace the forms associated with the signifiers to an ultimate foundation or grounding or arche. This linkage to such a grounding is believed to render the signifier authoritative. This trace of signifiers to a presupposed archemedian point characterizes the meaning constituting acts of expert knowers of the authoritative discourse. The meaning constituting acts of expert knowers of the authoritative signifiers point to an object beyond the experiences of the experts and beyond the experiences of $\mathrm{K}$. The arche is believed to stand alone as an objectivity of representation.

In contrast, $\mathbf{K}$ draws his forestructures of meaning as he intends his meaning-constituting acts. His objects of meaning are intended. They are not situated independently of his meaning constituting acts. Whereas the forms of authoritative play 'ground' themselves in further representations of given physical referents, it is only through $\mathrm{K}$ 's intentionality that he experiences forms and the signifiers which represent the forms. He thereby brings his life into the invisible forms as well as into the physical referents surrounding him. $\mathrm{K}$ presents his referents as he means his signifiers. The forms associated with the signifiers do not stand alone as an objectivity of representation. Rather, $\mathrm{K}$ presents forms and signifiers through his meaning conferring acts such that the direction of his acts are not fulfilled in a determinate context. Precisely because expert knowers direct their meanings toward an arche presupposed to be situated beyond all accessible meanings enclothing signifiers, the object intended remains radically different for the expert knowers than for K. K's acts will invariably remain unfulfilled when his only respondent is a claimant to expert knowledge of authoritative signifiers. $\mathrm{K}$ will invariably present the objects of his meaning conferring acts when the object of the experts' discourse may, at best, be re-presented because it is believed to dwell in a realm beyond signifiers and phenomenologically before the posit of signifiers. The direction of K's acts cannot be fulfilled in a determinate context when the context is charged with signifiers which expert knowers consider to be authoritative. K's meaning conferring acts make his pain perceptually apparent. K's meaning conferring acts thereby perpetually magnify his pain.

It seems that $K$ 's phonemes simply cannot recognize the sound pattems of the stories which the Uncle, Leni, and the Painter re-tell him. Being unable to recognize them as sound patterns familiar to his own chains of signifiers in his life-world, $\mathrm{K}$ cannot bring meaning into the stories. The stories remain empty for him, though fulfilled for the narrators inter se in that the stories make 'sense' for the expert listeners. Each intentional act always has the possibility of fulfillment. And this possibility poses the very frustration which $K$ experiences from event to event as he encounters the responses of one self-styled expert after another. For, to sustain their own roles in the juridical pyramid, they must direct their meanings to the inaccessible will of an Other who is believed to dwell before $\mathrm{K}$ 's utterances, indeed, before legal language itself. If the experts were capable of narrowing concrete circumstances into a range of objects which $\mathrm{K}$ 's meanings could direct, then his meaning constituting acts would become fulfilled. His meanings would become concretized. His typifications associated with his signifiers would grasp the re-told stories as referents. But because the experts can never reach that point by virtue of their search for a ground or arche of the Law, $\mathrm{K}$ 's meanings always remain open and frustrated.

\section{CONCLUSION}

Is it possible to retrieve a social relation between expert knowers and $\mathrm{K}$ such that the meaning constituting acts of each is fulfilled in the other? Such a retrieval would have to involve partners who respond to each other's utterances. For such a responsive relation to occur, a finality would have to characterize each partner's utterance. Without a finality. 
an utterance leaves no opening for the other to join in communication, Mikhail Bakhtin describes a responsive relation as dialogic. ${ }^{21}$

The question - paradoxically, the foundational question if I may use that word - is whether such a dialogic relation can emanate from the expert knowers of legal language in a modern state. For the experts claim to know the forms associated with chains of signifiers which they trace backwards to some grounding in a noumenal realm purged of all experience. The arche of all legal forms, though, is believed to be situated beyond such a trace. The arche is inaccessible from within the chains of signifiers familiar to the expert knowers. As such, the object towards which the expert knowers direct their meaning constituting acts will invariably remain unfulfilled and, therefore, indeterminate. As a consequence, the authoritative language of the modern state remains and must remain monologic just as Kafka describes with such stark realism in The Trial. The listeners and respondents enter the monologue indirectly in the name of the inaccessible will of the arche of The Law. The expert knowers may identify relevant facts, categorize them and analyze their categories in a search for the object intended by the founding auctor of the arche-median point. The objects intended by the non-expert are lost or assimilated in this project. The juridical project colours over the meant differences of non-experts and, in their place, the phonemes of expert knowers reconstitute a new world of juridical altemity which is erroneously taken by the experts as the true/real.

Kafka exposes the transformation of modern social relations with a piercing nakedness. He does so by leaving us with a question which contemporary legal theorists have yet to face: is it possible for the nomos of a modern state to be dialogic when the object intended in the meaning constituting acts of the expert knowers is presupposed to dwell in a noumenal realm beyond the experiences of expert and non-expert alike. That is, do the claimants to an expert knowledge of legal forms in a modem state manifest a monologue such as one observes of the selfstyled experts in Franz Kafka's The Trial? Is it possible for the language of expert knowers to reach the objects intended in the meaning-conferring acts of non-experts when they authorize their own meanings in the name of a presumed objective arche or foundation situated beyond their own meanings?

University of Windsor, Faculty of Law Windsor

\section{REFERENCES}

1 Franz Kafka, The Trial (NY: Schocken, 1937, 1956, 1964).

2 Scarry, Elaine, The Body in Pain: The Making and Unmaking of the World (Oxford: Oxford University Press, 1985).

See, e.g.. Alan Udoff, ed., Kafka and the Contemporary Critical Performance: Centenary Readings (Bloomington: Indiana University Press, 1987).

- Derrida, "Before the Law", in Acts of Lirerature, ed. by Derek Altridge (New York/London: Routledge, 1992): 181-220.

3 Jean-Francois Lyotard, The Differend: Phrases in Dispute, trans. Georges van den Abbecle (Minneapolis: University of Minneapolis Press, 1988; Theory and Hisfory of Liserature, vol 46).

- Kafka, supra, note I, 124.

Ibid., p. 151.

lbid., p. 119

- lbid., p. 72.

10 lbid.. pp. 193-194.

"Vygotsky. L. S., Thought and Language. Eugenia Haufmann \& Gertrude Vaker trans. \& ed. (Boston: MIT Press, 1962). Von Uexkull, Jacob. Theoretical Biology. D. L. Mackinnon trans. (London: Kegan Paul, 1926); "The Theory of Meaning" in Semiotica, vol. 92, no. 1 (1982): 25-82.

12 lbid., p. 6.

13 Husserl, Logical Investigarions, vol. 2 (New York: Humanities Press, 1970) "Investigation VI", pp. 682-683.

14 Bbid.. "Investigation 1," p. 283. Husserl's emphasis.

is Jbid., "Investigation V;" p. 584.

16 Ibid., "Investigation I", p. 280.

17 lbid., "Investigation I", fn 1, p. 281.

18 Jbid., "Investigation VI", pp. 282-283.

19 Ibid., "Investigation VI", p. $68 \mathrm{t}$.

20 Ibid., "Investigation VI", p. 700.

21 Bakhtin, in Michael Holquist (ed.) The Dialogic Imagination, Irans. Caryl Emerson \& Michael Holquist (Austin: University of Texas Press, 1981). 